\title{
Smoldering Waldenstrom Macroglobulinemia
}

National Cancer Institute

\section{Source}

National Cancer Institute. Smoldering Waldenstrom Macroglobulinemia. NCI Thesaurus.

Code C155910.

Waldenstrom macroglobulinemia with serum IgM monoclonal protein equal or more than $3 \mathrm{~g} / \mathrm{dL}$ and/or at least $10 \%$ bone marrow lymphoplasmacytic infiltration but no evidence of constitutional symptoms, symptomatic anemia, or hyperviscosity. (Blood $2008,112: 2709)$ 